\title{
Securing Afghan Women: Neocolonialism, Epistemic Violence, and the Rhetoric of the Veil
}

\author{
KEVIN J. AYOTTE and MARY E. HUSAIN \\ In the wake of the "war on terrorism," feminist analyses of international \\ relations must broaden the concept of security to consider forms of vio- \\ lence beyond the statist security framework of realpolitik. This article \\ argues that U.S. representations of the burqa rhetorically construct the \\ women of Afghanistan as gendered slaves in need of "saving" by the West, \\ increasing women's insecurity by promoting various forms of neocolonial \\ violence. In negotiating a middle ground between poststructuralist and \\ materialist methods, this essay also argues for a feminist postcolonial \\ criticism that will provide a more nuanced understanding of the nature \\ of gender insecurity in the post-cold war world.
}

Keywords: Afghanistan / burqa / international relations / postcolonialism / veil / violence

The concept of "security" has not always been considered particularly problematic in the study of international relations. For much of the twentieth century, and to a significant degree today, much of the theory and practice of international relations has been conducted from within the perspective of political realism, realpolitik, or its derivative, neorealism (Desch 1996, 361; Vasquez 1983, 160-72). Within the realist paradigm, security flows from power, specifically state power and military strength. Recent feminist scholarship has challenged this notion of security on the grounds that women have never been secure within (or without) the nation state-they are always disproportionately affected by war, forced migration, famine, and other forms of social, political, and economic turmoil (Mohanty 2002, 514; Tickner 2001, 50-1). The statist theoretical framework of political realism is thus inadequate to explain the myriad conditions that make women insecure in the world today. In the wake of the "war on terrorism" and its mobilization of women's bodies to justify U.S. military intervention in Afghanistan, feminist analyses of international relations must broaden the concept of security, in J. Ann Tickner's words, to "seek to understand how the security of individuals and groups is compromised by violence, both physical and structural" $(2001,48)$. To the types of violence examined by feminist international relations scholarship, we would add the concept of epistemic violence (see Spivak 1999, 266).

While the physical and structural violence inflicted upon women must remain a central component of feminist theory and criticism, the war on terrorism in Afghanistan also demonstrates that the Western 
appropriation and homogenization of third-world women's voices perform a kind of epistemic violence that must be addressed along with material oppressions. ${ }^{1}$ This essay argues that representations of the women of Afghanistan as gendered slaves in need of "saving" by the West constitute epistemic violence, the construction of a violent knowledge of the thirdworld Other that erases women as subjects in international relations. In claiming to secure Afghan women from the oppression of the Taliban, the United States has reinscribed an ostensibly benevolent paternalism of which we should remain wary. In particular, the image of the Afghan woman shrouded in the burqa has played a leading role in various public arguments seeking to justify U.S. military intervention in Afghanistan following the 9/11 attacks. This rhetorical construction of Afghan women as objects of knowledge legitimized U.S. military intervention under the rubric of "liberation" at the same time that it masked the root causes of structural violence in Afghanistan. The pursuit of gender security must therefore account for the diverse ways in which the neocolonialism of some Western discourses about third-world women creates the epistemological conditions for material harm. Although the distinctions among epistemic, physical, and structural violence in this article allow for analytic precision in the sense that these forms of violence are indeed different in kind, we must recognize their complicitous relationship.

The insecurity of Afghan women, discursive and material, also reflects and inflects some rather long-running theoretical debates within feminism. Disputes about the representation of race and class (or lack thereof) in feminist politics, for example, fragmented numerous organizations and movements over the past several decades, just as theoretical debates about difference and essentialism have splintered feminist intellectuals. The case of the U.S. appropriation of Afghan women and the burqa demonstrates the unsustainability of these theoretical divides. The material oppression of women in Afghanistan cannot be reduced to an array of floating signifiers; equally clear, however, is the danger of reducing representations of material conditions to the purported essence of Afghan women. Through rhetorical criticism of U.S. representations of Afghan women, this essay argues for a theoretical synthesis that will provide a more complex understanding of the nature of gender insecurity in the post-cold war world. The first section of this article briefly reviews relevant theoretical debates within feminism and feminist international relations in order to demonstrate both the value and the limits of discrete critical approaches and to lay the foundation for the middle ground adopted later. The second section examines specific U.S. representations of Afghan women and the burqa and considers the ways in which these discourses inflict and entrench certain forms of epistemic, physical, and structural violence against women. The conclusion explores alternative representations of Afghan women that offer the prospect of greater 
security through both critical reflexivity and the promotion of women's agency via indigenous social activism.

\section{"Postmodern" Theory, International Relations, and Feminist Praxis}

Because the postcolonial theory used in this article draws heavily upon poststructuralist insights, a brief overview seems in order. As Chandra Mohanty observes, "[f]aulty and inadequate analytic frames engender ineffective political action and strategizing for social transformation" $(2002,515)$. Some feminist scholars have used the poststructuralist disarticulation of linguistic representation from ontological essence to demonstrate both the arbitrariness of various ideas about gender and the role of language in constructing those ideas. Postcolonial feminism has been particularly critical of representations of "third-world women" in Western feminist discourses. Gayatri Spivak argues that, in some of these discourses, "'woman' is important, not race, class, and empire" $(1999,409)$. Without minimizing the importance of gender or biological materiality, Spivak's point is that the conditions experienced by women in the third world cannot be reduced only to gender or biology; exploitation by multinational capital, the deeply etched racism not only among some indigenous populations but also in the legacy of colonial relations between "first" and "third" worlds, and a host of other factors all conspire to oppress women. Moreover, one of postcolonialism's most trenchant insights has been the untenability of homogenized depictions of thirdworld women that essentialize the third world as if it were a singular locale. Such homogenization slips all too easily into the exoticization of the foreign Other, often tinged with an ethnocentric kind of pity for the oppressed's condition that reads in a manner similar to colonial texts proclaiming the need to save the oppressed from themselves (Mani 1998). The goal of postcolonial feminism is therefore often framed as a deconstructive genealogy of "the production of the 'third world woman' as a singular monolithic subject in some recent (Western) feminist texts" (Mohanty 1991b, 51). The connections between postcolonial theory and postmodernism, however, have raised concerns with some about the political implications of postcolonial critique.

The concept of, and a certain respect for, irreducible difference upon which deconstruction and much of postcolonial theory is founded have often been accused of fostering cultural relativism (e.g., Moghissi 1999, 52-3). While respect for the unique experience, history, and traditions of other cultures is a sentiment to which few would object, cultural specificity should not be used to justify unjust or oppressive practices. Moghissi argues, however, that "the postmodern relativists collude with 
the fundamentalists' culturalist solutions to crises of modernity and of modernization" (8). The sweeping generalizations about postmodernism as well as fundamentalism remain problematic in Moghissi's work, yet her worry should resonate with any feminist scholar. No theory should leave us passively accepting behaviors that threaten the basic dignity of human beings. Nonetheless, the attribution of relativism to all theories carrying the whiff of postmodernism needs to be greeted with skepticism. ${ }^{2}$ The violations of human dignity inflicted upon women (and men) all over the globe do, however, require that so-called postmodern frameworks account for the material conditions of discrete historical-cultural contexts. The complementary application of poststructuralist and materialist criticism thus allows for the most comprehensive analysis of the epistemic, physical, and structural effects that follow from U.S. discourses about the oppression of women in Afghanistan. The need for such a theoretical rapprochement is especially significant in the feminist study of international relations. Christine Sylvester, for example, warns of the problem faced by some poststructuralist versions of Critical Security Studies that avoid accounting for gender either as a factor in the material conditions under which women live or as a symbol for political organizing $(1994,182)$. Postcolonialism is especially apt for engaging this theoretical divide as it brings to the forefront the intimate relationship between discursive representation and material conditions.

\section{The Violence "Behind the Veil"}

There seems to be considerable agreement that the burqa, the heavy garment that covers the entirety of a woman's body with only a narrow mesh screen for vision, has become the universal symbol of women's oppression in Afghanistan (Kensinger 2003, 2; Abu-Lughod 2002, 785). In the context of the Taliban's harsh imposition of the mandatory burqa for all Afghan women, where the smallest deviation in dress was often met with public violence, such symbolism is easy to understand. It has been well documented that women in Afghanistan have been beaten simply for accidentally letting an inch of skin show (United Nations 2000, 7; Amnesty International 1999; Physicians for Human Rights 1998, 52). Of course, the Taliban's overwhelming misogyny neither began nor ended with the imposition of the burqa, and the wide range of oppressive policies that the Taliban inflicted upon women has certainly been discussed in the U.S. news media. Yet in many cases, representations of the burqa have come to stand in for all of the other violence done to Afghan women by an either visual or linguistic synecdoche.

It is not only the rhetoric of "the veil" that is significant in U.S. discourses about Afghan women but also the position of the speaking 
subject. ${ }^{3}$ Especially problematic is the ventriloquism of Afghan women by discourses speaking for (both "on behalf of" and "in place of") them. For example, Vicki Mabrey reported on CBS's 60 Minutes II that, "for the women of Afghanistan, the veil, the burqa, has become the symbol of the Taliban's power" ("Unveiled" 2001). Of course, in one sense this may very well be perfectly accurate, and the point of identifying this moment is not to suggest that U.S. women (or men) should not speak of other peoples' oppression. The key is to maintain a constantly reflexive skepticism toward the adequacy of our own (U.S.) representations of the "plight" of third-world women. Although Mabrey does interview women from Afghanistan, we must recall that "Huma," "Sonia," and the others interviewed in the news program are always already ventriloquized by the media narrative. Even if their accounts could be unproblematically interpreted as immediate and generalizable reflections of reality, that discourse has already been edited, prompted by certain lines of questioning, i.e., mediated. This is not to suggest that the women's stories are false, but rather that even their indigenous narratives are inflected by their representation in an inevitably Western discourse (Spivak 1999, 49).

In writing primarily of the U.S. appropriation of the third world through representations of Afghan women, it would be a mistake to suppose that the criticism articulated here can adequately represent the essential content either of "the West" or of the subject position occupied by Afghan women. As Spivak urges, the imperative "is to fix the critical glance not specifically at the putative identity of the two poles in a binary opposition, but at the hidden ethico-political agenda that drives the differentiation between the two" $(1999,331-2)$. Thus, while our primary concern is to deconstruct the agenda driving particular representations of Afghan women, we must also acknowledge the need for a simultaneous deconstruction of our decision to identify the particular poles in the binary critiqued by our own discourse. The last section of this essay will therefore make explicit that, in seeking to make visible the rhetorical operation of U.S. discourses about Afghan women, there is indeed a political agenda implied by our identification of the first/third worlds problematic in representations of the burqa. As we will see in the next section, the greater danger arises when such agendas are masked as pure benevolence.

\section{Epistemic Violence}

Postcolonial feminists have long recognized that paternalistic Western representations of third world women in need of saving by white Europeans are not benign (Mohanty 1991b, 72). Although the West's appropriation and construction of the third-world Muslim woman is not a new phenomenon, in the aftermath of 9/11 the circulation of images of veiled females reached epic proportions. U.S. media quickly capitalized on the 
veil as a visual and linguistic signifier of Afghan women's oppression. Burqa-clad figures, potent political symbols of the "evil" of the Taliban, were suddenly everywhere.

Our intent is neither to support nor repudiate Islamic covering practices. Rather, we argue that U.S. discourses homogenize an extraordinarily diverse population of Muslim women. Noticeably rare in the U.S. construction of the Afghan woman is an explication of the origins, variety, and underlying meanings of these practices that have shifted across historically specific cultural contexts (Mohanty 1991b, 67; Mojab 1998, 21). Although an exhaustive description of covering practices would be impossible, a brief foray into their variety will help to highlight the false homogeneity of U.S. representations. Contrary to popular misconceptions, these cultural practices originated prior to the rise of Islam (Ahmed 1992, 5). ${ }^{4}$ The monolithic image of the Taliban-imposed burqa is also just one among many covering "styles," a phrase that seems oxymoronic in light of the often homogenous portrayal of Islam in Western media (Abu-Lughod 2002, 786).

Meanings of oppression are certainly not intrinsic to Islamic covering practices but are socially constructed through discourse. Covering has functioned in a multiplicity of ways throughout time. For example, its use as an expression of agency (e.g., in the resistance movements against secular governments in Turkey, Egypt, Algeria, and Iran) has been elided by Western media (Mojab 1998, 20). In some Middle Eastern countries, covering signifies the initiation of women into fundamentalist resistance movements (Franks 2000, 919). During the 1979 revolution, middle-class Iranian women "veiled themselves" as a symbol of protest against the Shah and "Western cultural colonization," or as a means of expressing their solidarity with working-class women (Mohanty 1991b, 67).

Post-9/11 archetypal representations of oppressed burqa-clad women often ignore its utilization by Afghan feminists. The burqa provided an effective cover for smuggling books and supplies to a network of underground schools, cameras for documenting Taliban abuses, and women fleeing persecution (Kensinger 2003, 7). ${ }^{5}$ Some feminists have vehemently challenged the idea that these practices can be "empowering" (e.g., Moghissi 1999, 42-7). However, as Mohanty remarks, "[t]o assume that the mere practice of veiling women in a number of Muslim countries indicates the universal oppression of women through sexual segregation not only is analytically reductive, but also proves quite useless when it comes to the elaboration of oppositional political strategy" $(1991 b, 67)$. The consequences of such analytical reductionism are not merely theoretical; homogenization of Muslim covering practices partakes in exactly the paternalistic logic that underlies the neocolonial politics of U.S. efforts to "liberate" Afghan women according to an explicitly Western model of liberal feminism. 
The U.S. appropriation of the burqa after $9 / 11$ is reminiscent of depictions of women in colonial territories, and colonial discourses provide helpful analogues for the present analysis. For example, Spivak provides a rigorous critique of the paternalistic feminism that informed the British colonial ban on sati in India $(1999,285-7)$. In British accounts of this practice, in which a widow would immolate herself on her husband's funeral pyre, the voice of women who practiced sati was always absent (287). As Spivak remarks, "[t]he agency was always male; the woman was always the victim" (298). In other cases, Western discourses displayed a sexualized Orientalism without any explicit interest in alleviating women's oppression (see Said 1979). French colonial postcards of Algerian women during the early 1900s, for instance, systematically distorted Muslim women, producing rather than reflecting reality in a bizarre amalgam of "eroticism and exoticism" for their European audience (Schick 1990, 350).

French and British colonists focused on veiling in particular as the overarching symbol of the "degradation of women" and "the backwardness of Islam" (Ahmed 1992, 152). It was against this historical context that Ahmed coined the term "colonial feminism" to describe feminism "used against other cultures in the service of colonialism" (151). For example, in Egypt, Lord Cromer championed the cause of unveiling women, claiming the veil was constraining their "mental and moral development" (153). The colonial impulse behind Cromer's concern for Egyptian women becomes more obvious when his "feminist" sentiments are juxtaposed to the hypocrisy of his position as a founding member and president of the Men's League for Opposing Women's Suffrage. In Algeria, French generals bused village women into Algiers for a carefully choreographed unveiling by French women as evidence of indigenous support for the French occupation (Lazreg 1994, 135).

Whether in the context of covering or uncovering, collapsing differences among Muslim women through the use of the burqa as a generalized symbol of female oppression performs a colonizing function. Under such assignment, women's status as objects remains fixed since they are denied the power to speak of differences, their placement in the existing first/third-world imperialistic order secured (Mohanty 1991b, 73). In contemporary U.S., as in European colonial, discourses, "[t]he domesticated, subjugated, unenlightened Other as opposed to the liberated, independent and enlightened Western self was used as a moral prop to legitimize colonial power relations" (Moghissi 1999, 15; see also Mohanty 1991b, 74). According to Mavis Leno, chair of the Feminist Majority Foundation campaign for women in Afghanistan, before the rise of the Taliban, women "lived an Islamic version of a contemporary American woman's life" and "[t]hey dressed as they wished" ("Mavis Leno" 2001). The U.S. woman was thus cast as an ideal to which Afghan women could aspire as a result of their "liberation." Although the variations in the plethora of news 
reports flooding print, broadcast, and internet media make an exhaustive catalogue impossible, three rhetorical patterns can be discerned in the following examples that are illustrative of the epistemic violence inflicted by certain U.S. discourses about Islam, Afghan women, and the burqa. These rhetorical patterns include the demonization of the burqa, the homogenization of Islam, and the fetishization of "unveiling."

First, many U.S. discourses demonize or deride the burqa itself, rather than the garment's imposition by the Taliban, and in so doing unwittingly obliterate vital aspects of feminist agency for Afghan women. For example, a Time magazine article entitled "About Face" featured photographs of nameless women wearing the ubiquitous burqa, "to Western eyes a kind of body bag for the living" (Lacayo 2001, 36). In an exposé on refugee camps in Pakistan sponsored by the Revolutionary Association of the Women of Afghanistan (RAWA), Barbara Walters contrasted the freedom in the camp with the "dehumanizing veil" mandated by the Taliban ("Revolutionary Afghan Women's Association Explains" 2001). While the Taliban's enforcement of the burqa and the punishments for noncompliance were clearly destructive of Afghan women's agency, the phrasing of the above excerpts makes clear that it is the burqa itself that is to be considered sub-human. By vilifying the burqa, such representations offer no possibility for women to choose to wear it out of personal preference or cultural tradition. In some cases, the dehumanization of Afghan women was quite explicit as journalists referred to burqa-clad women as "ghosts" (Ozernoy 2001, 30; Roane and Ozernoy 2001, 22). Significantly, the term "ghost" defines Afghan women wearing the burqa, not the Taliban's abuses. To the extent that this representation is accepted as valid by reading audiences, Afghan women could never exercise agency in the form of a choice to adopt the burqa and remain human. Another article in Time, laudably providing brief descriptions of the diversity of Muslim covering practices (e.g., chador, niqab, hijab, burqa), carried the title "Headgear 101" (Song 2001,31). The problem lies in the derisive simplification of the complex cultural dynamics of covering practices as "headgear." The neocolonial assumptions underlying this seemingly innocuous language choice in the title become more obvious when one compares the apparent acceptability of the title when applied to Muslim covering practices to the unlikelihood that widows' veils or the Papal miter would be dubbed "headgear" by U.S. journalists. A similar tone of derision can be discerned in the description of the burqa, worn by choice by a woman in Kabul after the fall of the Taliban, as a "costume" (Gibbs 2001, 39). In all of the examples above, the overt vilification or subtle mockery of the burqa becomes a rhetorical technique whereby U.S. discourses inflict epistemic violence on Afghan women by denying the very possibility for agency through the choice of dress, ostensibly the cause at issue with these representations in the first place. 
Second, the distinction between "liberated" U.S. women and "unenlightened" Afghan women is often amplified by ethnocentric criticisms of a homogenized Islam. For example, one Time article entitled "The Women of Islam" implied that the oppressions it described in some countries are intrinsic to Islam, a notion emphasized by the subtitle "nowhere in the Muslim world are women treated as equals" (Beyer 2001, 50). Here, despite the article's overt attempt to describe the diversity of Islamic practices among Malaysia, Iran, Egypt, Pakistan, Saudi Arabia, and Kashmir, there is still a discursive commitment to the religious and geographic homogeneity of Islam in the language of a "Muslim world." The infinite differences among these countries melt away as they become fixed in the space of a separate Islamic "world" to which they are assigned. At the same time, the religious diversity within each of the countries named in the article vanishes as the label of Islam comes to exhaust the meaning of religion under those signifiers. ${ }^{6}$ The ethnocentrism inherent in the idea of a "Muslim world" can be discerned when one contemplates the likely outcry that would follow the identification of Euro-America as a "Christian world." The neocolonial notion of Islam as a marginal Other to the West is particularly evident in the fact that "the women of Islam" are all portrayed as Middle Eastern or Asian, despite the enormous and growing Muslim population in North America and Europe. Once again, the signifier "Islam" undergoes an Orientalist transformation into one pole of a binary opposition, the signified "non-Western."

Third, the fetishization of "unveiling" so pervades many U.S. accounts of Afghan women's oppression that it has come to serve as its own complex rhetorical trope. Loretta Kensinger notes how a wide range of news media in the United States not only used the image of the burqa when representing Afghanistan, but also "celebrated the veil's lifting as the U.S. bombs fell" $(2003,15)$. The cover of the 3 December 2001 issue of Time featured the picture of a woman wearing a simple headscarf; the headline reads, "Lifting the Veil." An article in Newsweek acknowledged that many Afghan women were still wearing the burqa after the fall of the Taliban but suggested they were "waiting [to unveil]" to see whether victorious Northern Alliance forces were "serious about women's liberation" (Liu 2001, 46). While freedom from imposed covering is obviously an imperative right for Afghan women, these representations once again vilify the burqa itself and thereby elide the agency of women who might choose various forms of covering practices. Worse, the Newsweek article attributes the agency for liberation solely to the (male) Northern Alliance fighters while Afghan women await their approval. Other accounts of "unveiling" objectify Afghan women with less than subtle sexual figurations. In a story on women living under the Taliban regime, Tom Brokaw enticed viewers by explaining that this story would provide "a rare look 
behind the veil" ("Life of Women" 2001). The 60 Minutes II segment entitled "Unveiled" promised that the viewer would meet young Afghan women who "unveil more than just their faces" ("Unveiled" 2001). This last instance is particularly noteworthy as an example of how many of these seeming celebrations of the liberation of Afghan women from the burqa implicitly rely on the voyeuristic Orientalism of a promise to uncover women's bodies. The common theme running throughout this trope of "unveiling" is the reduction of Afghan women's agency to their conformity to popular U.S. notions of feminist liberation.

To erase the diverse and contextually specific experience of Afghan women regarding covering practices inflicts epistemic violence by devaluing them as subjects (Spivak 1999, 291; Mohanty 1991b, 71). U.S. representations of Afghan women only or primarily as objects victimized by (even the Taliban's) male agency ineluctably reduce knowledge of these women to their status as victims. This discursive elision of varied indigenous practices and the knowledge regarding their contextual values can only be described as a "violent" imposition on Afghan women's subjectivity. As demonstrated above, the subjectivity of Afghan women-and third-world women in general - is not exhausted by their victimization in patriarchal and misogynist contexts. Some discourses about the burqa, however, ironically parallel the violence of sati by performing a metaphorical burning of the subaltern subject in neocolonialist expressions of U.S. feminism. The violence wrought by the rhetoric of the veil is not, however, limited to epistemological registers.

\section{Physical Violence}

The infliction of violence against women's bodies, in the form of assault, rape, and murder, is clearly the most visible manifestation of misogyny. To the extent that physical brutality ultimately threatens the very existence of the subjects on which it is imposed, we might plausibly say that physical violence against women is the most significant concern out of the various types of violence discussed in this article. Yet the obviousness of physical violence should not lead us to think that violence against women is a theoretically or historically simplistic phenomenon. Women in Afghanistan were most certainly the victims of terrible physical violence at the hands of the Taliban. At the same time, we must take seriously the call from feminist international relations scholars to examine "the ways in which governments and the military use, and alter, prevailing discourses about gender to their own ends" (Whitworth 1994, 26). While U.S. expressions of concern for the well-being of Afghan women were indeed valuable for raising the profile of efforts to address the conditions for women in Afghanistan, we must turn a critical eye toward the appropriation of feminism to justify U.S. military intervention. 
Tickner has observed that military violence between nation-states is always legitimized by some instantiation of "[t]he concept of the 'protected" $"(2001,57)$. In other words, the military pursuit of geopolitical security necessarily involves a specification and definition of the object, persons, or ideas that are being secured. Following the incredible devastation caused by the attacks on 9/11, one might logically expect that the physical safety of U.S. bodies would be the primary security concern in U.S. public discourse, and in fact it was. The sudden upsurge in public discourse about the gendered oppression of Afghan women after 9/11, however, reveals that an enormous amount of governmental and media effort was expended in reframing U.S. military intervention as the securing of Afghan women from the ravages of the Taliban. It is not enough to argue that these representations of Afghan women were simply part of a propaganda campaign to justify U.S. military action, as the oppression of and violence against Afghan women was a demonstrable material fact. The more important question to ask is: how does one trace the ideological and material consequences of such representations?

The oppression of women in foreign lands has often been a discursive tool of statecraft seeking to justify military intervention. As Moghissi notes, issues of women's rights have long been "used ideologically to isolate and contain adversaries of great powers" (1999, 4). Representations of women's oppression have fit particularly well into patriarchal social mythologies whose own devaluation of women has been cloaked in terms of a need to "protect" women from the harshness of certain jobs or political responsibilities. In such social myths, women are characterized primarily as victims in need of saving by the paternalistic masculinity of patriarchal social or governmental institutions. This formula extends to the realm of international relations, where "the heroic, just warrior is sometimes contrasted with a malignant, often racialized, masculinity attributed to the enemy" (Tickner 2001, 57). Following 9/11, it was not only the Taliban as supporters of terrorism, but also the Taliban as oppressors of women, that defined our enemy in the "war on terrorism." In the U.S. government's appropriation of the feminist concern with women's oppression, U.S. military action became "just" in part as the agency of Afghan women's liberation.

The U.S. government and media made substantial use of "the maltreatment of women and their exotic attire" to represent the "moral, cultural and political deficiencies of the Islamic world" as part of the warrant behind the 1991 Gulf War (Moghissi 1999, 37). More recently, gender oppression under the Taliban became a justification for U.S. military intervention to topple the oppressive regime. In a televised address to Congress on 20 September 2001, George W. Bush identified the Taliban prohibition on education for women as part of the background for his demand that the Taliban give up the al Qaeda members hiding in Afghanistan 
(G. Bush 2001). Significantly, the succor of Afghan women was not going to be achieved in any way by the fulfillment of Bush's demands; at that moment of history, the Taliban's compliance would have left gendered oppression in Afghanistan intact because surrendering bin Laden would have kept the same regime in power. The representation of women's oppression was employed partly to demonize the Taliban and to prepare the U.S. public (and the world) for the air strikes that began on 7 October 2001. It is beyond the scope of this article to evaluate comprehensively the justification for air strikes against Taliban targets, and it cannot be claimed that representations of burqa-clad Afghan women were responsible for the U.S. decision to attack the Taliban, since the air strikes began before the majority of discourse about the burqa appeared in U.S. media. However, the epistemic violence done by eliding the agency of Afghan women in their representation only as passive victims played a crucial role in justifying the particular forms of military action taken, even after the fact. Because U.S. discourses about Afghan women suggested that they could not "save" themselves, "liberation" had to come from the outside. While the sheer number of these portrayals makes an exhaustive analysis impractical, one particularly well-publicized event provides an explicit illustration of the appropriation of feminist struggles against gender oppression in the service of the war on terrorism.

Laura Bush's delivery of the president's "Weekly Radio Address" on 17 November 2001 was the first time that entire address had been delivered by a first lady. The forum of this particular speech is, of course, itself significant; speaking what is normally the president's address, Laura Bush effectively became the voice of the U.S. government on the subject of women's oppression in Afghanistan, far beyond the authority she already carried as first lady. Moreover, the fact that she is a woman was undoubtedly the reason that she, rather than President Bush, delivered this speech on this topic; White House strategists likely assumed that audiences would be more apt to identify with a woman speaking on "women's issues." Although President Bush also routinely referenced Afghan women's oppression, Laura Bush's position as a woman implies that her discourse should be the discourse of every woman concerned about sexist oppression (and every man interested in "saving" women in need of rescue). Finally, Laura Bush's delivery of this address makes convenient use of the stereotype of women as nonviolent in contrast to male aggressiveness; the call for military action becomes more persuasive because, when a woman advocates violence, supposedly there must be no other recourse.

This radio address is peculiar, however, in that it locates the cause of Afghan women's oppression not only in the rule of the Taliban, but more specifically in the threat of terrorism, and al Qaeda in particular. According to Laura Bush, "[t]he fight against terrorism is also a fight for the 
rights and dignity of women" (L. Bush 2001). Although the Taliban regime codified in law the obligatory burqa as well as the vast array of brutal punishments inflicted upon women, Laura Bush repeatedly attributed the oppression of women directly to "terrorists" and al Qaeda. For example, she described "the brutality against women and children by the al Qaeda terrorist network and the regime it supports in Afghanistan, the Taliban" (L. Bush 2001). In this instance, not only is al Qaeda the agent of Afghan women's oppression, but al Qaeda is also cast as the agency behind the Taliban's political rule. Although the Taliban clearly provided shelter and aid to the terrorist organization, to imply that al Qaeda was the primary force behind the Taliban's rule would be a gross misinterpretation of available evidence. Furthermore, if responsibility for the oppression of women in Afghanistan can be laid at the feet of al Qaeda because of the mutually supportive relationship between al Qaeda and the Taliban, surely the past U.S. support for the Taliban during its proposed pipeline deal with Unocal and cold war assistance to the Mujahadeen (from which both al Qaeda and the Taliban sprang) makes the United States partly culpable as well (Abu-Lughod 2002, 787). The historical amnesia regarding U.S. complicity with the Taliban prior to 9/11 reveals the ideological work pursued in Laura Bush's radio address and the need for feminist international relations criticism attentive to neocolonial ambitions as a component of the oppression of third-world women.

Laura Bush's location of the source of Afghan women's oppression in "the terrorists" provides ample evidence that the strategic goal behind this address was the legitimization of U.S. military intervention in Afghanistan, not the protection of Afghan women. Laura Bush repeatedly identified "the terrorists and the Taliban" as the oppressors of Afghan women. Even the grammar of her discourse placed "the terrorists" before the Taliban, as if to imply that the conditions imposed upon Afghan women were primarily designed by al Qaeda. At one point in the address, Laura Bush's desire to attribute gender oppression to al Qaeda reached almost absurd proportions, when she claimed that " $[\mathrm{t}]$ he brutal oppression of women is a central goal of the terrorists" (L. Bush 2001). While such an assertion begs the question, "Then why attack the World Trade Center?," the falsehood provides a convenient scapegoat whose "sacrifice" by the U.S. military is thus legitimized. The determination to emphasize terrorist misogyny was certainly not limited to Laura Bush. Barbara Walters, in a 20/20 story on the oppression of Afghan women, closed with a non sequitur reminding the audience that "the lead hijacker in the World Trade Center attack" had penned a will in which he disallowed women from attending his funeral ("Revolutionary Afghan Women's Association Explains" 2001). While the hijackers clearly were of like minds with the Taliban regarding the status of women in society, the equation of al Qaeda and misogyny seems to have more to do with the rhetorical vilification of the terrorists than it does with analytical perspicuity. 
In addition to the vilification of al Qaeda, Laura Bush also sought to justify U.S. military action by explicitly identifying the U.S. invasion with the liberation of Afghan women. In the radio address, she declared that "[b]ecause of our recent military gains in much of Afghanistan, women are no longer imprisoned in their homes" (L. Bush 2001). This assertion regarding the success of the U.S. military in increasing the security of Afghan women is especially pernicious. Conditions for women in Afghanistan are little better, and in some cases have deteriorated, since the beginning of U.S. air strikes (Human Rights Watch 2003). A recent report by RAWA states that suicide by Afghan women is much more frequent than under the Taliban's rule (Rawi 2004).

The failure of military intervention to bring about security for Afghan women will likely come as little surprise to feminist international relations scholars. The lack of public debate regarding civilian casualties following the U.S. invasion of Afghanistan offers a telling example of the material consequences that follow from the realist emphasis on state security in contrast to feminist notions of individual security from physical, structural, and epistemic violence. Some 1,300 Afghan civilians may have been killed directly by U.S. bombs and missiles. Even more significantly, estimates of "indirect victims" of U.S. military action who died as a consequence of the rigors of forced migration from their homes, the interruption of drought relief, and the upsurge in fighting between the Taliban and the Northern Alliance range from 3,000 to 7,000 (Conetta 2002). Of course, various media outlets and the U.S. government dispute these numbers. The U.S. government does not even track civilian casualties resulting from U.S. military action, ostensibly for reasons ranging from practicality to concerns about public opposition to "collateral damage." In fact, the disinterest regarding civilian casualties reflects the philosophical framework of realpolitik under which U.S. foreign policy is conducted. Within political realism, civilian casualties do not need to be counted because they do not figure as variables in a geopolitical equation that privileges the security of the nation-state over individual security from violence. In stark contrast to Laura Bush's sanguine confidence in the liberatory success of U.S. military intervention, a damning report by Human Rights Watch concluded that "[t]he situation today-widespread insecurity and human rights abuse-was not inevitable, nor was it the result of natural or unstoppable social or political forces in Afghanistan. It is, in large part, the result of decisions, acts, and omissions of the ... [U.S.] government, the governments of other coalition members, and parts of the transitional Afghan government" $(2003,11)$. To the extent that Western representations of the burqa and oppressed Afghan women were successful in persuading public audiences to support uncritically U.S. intervention in Afghanistan, the epistemic violence of such discourse wreaked physical violence on the bodies of Afghan women as well. 


\section{Structural Violence}

One of the most important advances in the history of feminism was the recognition of structural violence against women as a significant aspect of gender oppression. Structural violence includes the myriad material harms done to women through inadequate education and health care, exploitative employment conditions, endemic poverty, and other conditions that inflict damage on lives without the brute immediacy of physical violence. The analysis of structural violence is vital because it accounts for disadvantages that shorten or degrade women's lives and traces the sometimes convoluted causes to social, political, and economic structures. Rather than allowing these conditions to remain unexamined as a neutral part of the landscape, attention to structural violence imputes agency, and hence responsibility, to social, political, and economic actors for the maintenance of structural conditions that harm women.

Women in Afghanistan were subjected to structural violence long before, as well as during, the Taliban regime. Although the U.S. government certainly made use of representations of structural violence against Afghan women, the epistemic violence done to Afghan women by the homogenized, neocolonial, and paternalistic rhetoric of the veil shortcircuited any reflexive recognition of U.S. contributions to that self-same structural violence. As Abu-Lughod puts it, framing the oppression of women in Afghanistan as a problem caused solely by the Taliban's ruthless twisting of religion and culture "prevented the serious exploration of the roots and nature of human suffering in this part of the world" while "recreating an imaginative geography of West versus East, us versus Muslims" $(2002,784)$. Although arguably performed by every decontextualized image of a burqa-shrouded Afghan woman, Laura Bush's radio address exemplifies the erasure of history with the reduction of women's structural oppression in Afghanistan to "the central goal of the terrorists." To the extent that the Taliban, and even bin Laden himself, sprang from the U.S.-supported Mujahadeen, the absence of such history makes it possible to identify structural violence against Afghan women without achieving the reflexive recognition of U.S. complicity in maintaining those very structures. RAWA has noted, for instance, that in 2000 the United States gave $\$ 43$ million to the Taliban for reducing opium production as part of the "war on drugs" (Rawi 2004).

The identification of U.S. complicity in structural violence against Afghan women does not deny the viciousness of the Taliban. As even reports critical of U.S. intervention in Afghanistan admit, there is a significant consensus among women in Afghanistan that life is better now than under the Taliban (Human Rights Watch 2003, 12). To say that life is "better," however, does not excuse one from pointing out that the actions of the new Afghan government, and especially the warlords and elements 
of the Northern Alliance supported by the United States, promise continued structural violence against women (11). Despite a few putative legal protections for women, the material experience of Afghan women continues to be one of profound insecurity (Rawi 2004). Ultimately, U.S. discourses that associate gender oppression with covering practices while imputing all responsibility to the actions of the Taliban or al Qaeda mask the role of U.S. national security policies in perpetuating the insecurity of structural violence against women in Afghanistan.

\section{Alternatives}

The expansion of "security" in feminist international relations beyond the confines of realist definitions of nation-state interest was a prerequisite for taking seriously the myriad gendered practices that oppress both women and men throughout the world. The neocolonialism in many Western representations of third-world women demonstrates the extraordinary power of discourse to shape our understanding of the world. As has been argued in this essay, the epistemic violence inflicted on Afghan women through the U.S. appropriation and homogenization of covering practices makes possible (and more likely) the continuation of physical and structural violence against women in Afghanistan. The argument at hand has sought to identify the irreducible diversity of women's lived experience "against the grain of 'public' or hegemonic history" in order to challenge dominant political discourses that have elided Afghan women's agency as subjects (Mohanty 1991a, 38-9). Of course, counter-memory cannot nostalgically long for some lost "truth" of women's experience, but it can add texture to the always already woven tapestry that is the discursive representation of women.

We close this essay by offering an alternative representation of covering practices in Afghan society. In contrast to the epistemic violence wrought by representations of burqa-clad Afghan women on the Feminist Majority Foundation website, Kensinger describes the image of Meena Keshwar Kamal, founder of RAWA, on the latter organization's website. Kamal's image accompanies a counter-hegemonic discourse that requires viewers to confront Afghanistan's neocolonial cold war history with both the Soviet Union and the United States (Kensinger 2003, 8). The RAWA website also represents a far more effective call for the elimination of imposed covering. The RAWA argument contextualizes covering practices within and across cultures, noting that they are not unique to Afghanistan, Islam, or the third world. "[F]undamentalists" are identified as the root cause of the oppression of women. Through the use of inclusive language to explicate their position on "[t]he Islamic hejab (veil)," RAWA

avoids the myopic fixation on the burqa, a particular regime, or geographic 
locale, as is characteristic of many U.S. representations of Afghan women (Revolutionary Association of the Women of Afghanistan n.d.). RAWA's discourse thus opens up possibilities for transnational solidarity with women subjugated by diverse forms of "fundamentalism" independent of covering practices. The criticism in this article should therefore not be read as a condemnation of U.S. interest in gender equality in Afghanistan, but as a call for support of the experience and knowledge of indigenous activists working toward this goal. This reflexive alternative to uncritically speaking for others will be more productive when conducted as a collective enterprise with those others, "by which aspects of our location less obvious to us might be revealed" (Alcoff 1995, 112).

Against the portrayal of Islamic women in the United States post9/11, RAWA's website also accurately presents covering as a cultural, rather than religious, issue. When forcibly imposed, the burqa becomes a misogynistic instrument of terror designed to objectify women, relegating their social status to that of "chattel" by making them literally invisible in the Afghan public sphere. Although a call is issued for "rejection of the veil as a symbolic form of resistance," by recognizing and respecting the personal nature of individual women's decisions regarding covering, the social meaning of such practices is acknowledged in a fashion that preserves the agency of Afghan women while challenging the structural power at work through imposed covering (Revolutionary Association of the Women of Afghanistan n.d.). RAWA thus seeks to empower women through advocacy shaped by their shared experience of gender relations in Afghanistan (Brodsky 2003).

The RAWA website also emphasizes the gendered Taliban policies that target men, "a subtlety that disrupts any inclination to see the situation as simply one of Afghan men against Afghan women" (Kensinger 2003, 12). Although men cannot become members, male supporters play a vital role in RAWA, recognizing that it is "not only a woman's organization" (Brodsky 2003, 203). Philosophically and strategically, RAWA's vision and ongoing practice are consciously grounded in the struggle for democracy for all Afghans (194). Because of the cultural constraints on Afghan women's mobility and participation in activities outside the home, the support of men is vital. As one RAWA member explains, "[w]e are not anti-male. We also can't work without men" (193). Perhaps even more important than the elimination of the Taliban, raising the consciousness of Afghan men is one of the organization's greatest achievements and essential to their long-term goals (218). RAWA's activism, on multiple levels, thus avoids Spivak's concern about Western discourses that position white men as "saving brown women from brown men" $(1999,284)$.

The reductive representations of burqa-clad Afghan women in U.S. media and U.S. governmental discourse have inflicted their own sorts of violence-epistemic, physical, and structural-on the bodies of Afghan 
women. In addition to shedding light on the consequences of certain U.S. discourses that purport to rescue Afghan women from gender oppression, the analysis herein also demonstrates the need for a synthesis of materialist and poststructuralist approaches to feminist international relations theory. Critical attention to the material conditions experienced by women is necessary not only to identify the physical and structural violence inflicted on the bodies of women, but also to trace the diversity of women's experience that is flattened by many Western feminist discourses about third-world women. The insights of poststructuralism also demonstrate that the categories so often attributed to women are not essentially fixed, yet are frequently positioned as such by the very language we use with the most altruistic intentions. Both theoretical "poles" contribute to this analysis, and it is only by the refusal of both for the critical space in between that a more reflexive feminist praxis becomes possible.

Kevin J. Ayotte is an Assistant Professor in the Department of Communication at the California State University, Fresno. Correspondence should be sent to Kevin I. Ayotte, 5201 North Maple Avenue, M/S SA46, Fresno, CA 93740-8027; kjayotte@csufresno.edu.

Mary E. Husain is a Lecturer in the Department of Communication at the California State University, Fresno. Correspondence should be sent to Mary E. Husain, 5201 North Maple Avenue, M/S SA46, Fresno, CA 93740-8027; mhusain@csufresno.edu.

\section{Acknowledgment}

The authors would like to thank Maliha Zulfacar, Jahan Ara, the editors, and the anonymous reviewers for their invaluable assistance in the development of this article.

\section{Notes}

1. As several scholars have argued, the linguistic categories of "women," "third world," and "feminism" are neither as homogenous nor as fixed as their usage inevitably implies. This recognition is especially important when writing from a position of multi-faceted privilege in Western academia (Mohanty 1991a, 3-11; 2002, 505-6). Consequently, following Spivak (1987), we employ the terms "woman," "third world," "Western" and so forth not as "putative essence but in terms of words currently in use" $(1987,77)$. The nominalization of the "West" presents a special difficulty, as the generalization it implies may often be applicable at the same time that it risks flattening significant 
diversity among "Western" peoples and states. Because this article examines specifically U.S. discourses about Afghan women, we eschew generalizations of "the West" except where articulated by others or warranted by the context. Recourse to such generalizations may in fact be necessary as an element in the strategic essentialism of which all collective politics must sometimes partake; the simultaneous critical move must be to "keep the generalizing impulse under erasure, visible as a warning" (Spivak 2003, 46).

2. For instance, Moghissi claims that the rejection of modernity risks a "disastrous politics" $(1999,54)$, but the only example offered is the defense of clitoridectomy by a French academic named Raymond Verdier (60). While the present authors have no interest in defending clitoridectomy or Verdier, a single example does not a generalization prove.

3. The terminology used to describe the practice of covering parts of the body is complex. Beyond the variety of covering practices in terms of what is covered by cloth (just hair, hands, part of the face, or the entire body as with the burqa), there are substantial differences in generalized terminology. For example, while "veiling" is used almost universally in U.S. discourse to encapsulate all of these covering practices, some Muslim women, and especially Afghan women, use the term "covering practices" (Zulfacar 2004). However, many Muslim women and even the Revolutionary Association of the Women of Afghanistan (RAWA) website use the term "veiling." Perhaps an issue of translation, or the attempt to use a term with which Western audiences will identify, the prevalence of "veiling" terminology in U.S. discourses about the burqa may also be seen as yet another manifestation of the tendency to homogenize Muslim women. We use the generalization "covering practices" except where context or quotations dictate otherwise. For an extended discussion of the problematic etymology of "veiling," see El Guindi (1999, 6-12).

4. Iconographic images of covering practices date back to "Palmyra in the first century A.D" (Keddie and Beck 1978, 25). During the "ancient Greco-Roman, pre-Islamic Iranian and Byzantine empires," they symbolized elite social status (Hoodfar 2003, 6). They were then assimilated by Muslims during Islam's early expansion, during which non-Arab misogynistic ideologies were incorporated into Islamic law (Majid 1998, 335). Nowhere in the Qur'an is a particular covering practice explicitly prescribed, nor is there any unitary Islamic theological perspective on the matter (Hoodfar 2003, 6; Mojab $1998,23)$.

5. For example, RAWA's covert videotaping of the execution of Zarmeena in 1999 took a prominent role in their indigenous activism, although the images did not achieve visibility in the United States until CNN repeatedly broadcast the BBC documentary, Beneath the Veil (Harrison 2001), containing this footage in fall 2001 (Brodsky 2003, 14).

6. Although Beyer admits the impossibility of painting "one picture of women living under Islam today," she proceeds to categorize Muslim women by 
nationality $(2001,51)$. This move exemplifies the problems inherent in homogenizing difference. One of the present essay's authors lived in Pakistan and observed that the interpretation of Islam, including covering practices, varied enormously based on factors such as ethnicity, education, family custom, social class, and personal choice. The paternalism underlying the liberal feminist impulse in Beyer's article can be discerned in its discussion of Pakistan, where the article states that "most females are illiterate" while neglecting to mention that many Pakistani males are as well (55).

\section{References}

Abu-Lughod, Lila. 2002. "Do Muslim Women Really Need Saving? Anthropological Reflections on Cultural Relativism and Its Others." American Anthropologist 104(3):783-90.

Ahmed, Leila. 1992. Women and Gender in Islam: Historical Roots of a Modern Debate. New Haven, CT: Yale University Press.

Alcoff, Linda Martín. 1995. "The Problem of Speaking for Others." In Who Can Speak? Authority and Critical Identity, eds. Judith Roof and Robyn Wiegman, 97-119. Urbana: University of Illinois Press.

Amnesty International. 1999. Women in Afghanistan: Pawns in Men's Power Struggles, 1 November. Retrieved 8 January 2005, from: http://web.amnesty .org/library/index/ENGASA110111999.

Beyer, Lisa. 2001. "The Women of Islam." Time, 3 December, 50-9.

Brodsky, Anne E. 2003. With All Our Strength: The Revolutionary Association of the Women of Afghanistan. New York: Routledge.

Bush, George W. 2001. "Address to a Joint Session of Congress and the American People." 20 September. Retrieved 27 June 2004, from http://www.whitehouse .gov/news/releases/2001/09/print/20010920-8.html.

Bush, Laura. 2001. "President George W. Bush's Weekly Radio Address Given Today by First Lady Laura Bush." Federal News Service, 17 November. Retrieved 18 June 2004, from http://www.lexis-nexis.com.

Conetta, Carl. 2002. "Strange Victory: A Critical Appraisal of Operation Enduring Freedom and the Afghanistan War." Project on Defense Alternatives Research Monograph 6 (30 January). Retrieved 24 January 2005, from http://www.comw .org/pda/0201strangevic.html.

Desch, Michael C. 1996. "Why Realists Disagree About the Third World (And Why They Shouldn't)." In Realism: Restatements and Renewal, ed. Benjamin Frankel, 358-81. London: Frank Cass.

El Guindi, Fadwa. 1999. Veil: Modesty, Privacy and Resistance. Oxford, UK: Berg.

Franks, Myfanwy. 2000. "Crossing the Borders of Whiteness? White Muslim Women Who Wear the Hijab in Britain Today." Ethnic and Racial Studies 23(5):917-29.

Gibbs, Nancy. 2001. "Blood and Joy." Time, 26 November, 28-39.

Harrison, Cassian, dir. 2001. Beneath the Veil. Atlanta, GA: Cable News Network. 
Hoodfar, Homa. 2003. "More than Clothing: Veiling as an Adaptive Strategy." In The Muslim Veil in North America: Issues and Debates, eds. Sajida S. Alvi, Homa Hoodfar, and Sheila McDonough, 3-40. Toronto: Women's Press.

Human Rights Watch. 2003. "'Killing You Is a Very Easy Thing for Us': Human Rights Abuses in Southeast Afghanistan." Afghanistan 15(5):1-104. Retrieved 30 June 2004, from http://www.hrw.org/reports/2003/afghanistan0703/ afghanistan0703.pdf.

Keddie, Nikki, and Lois Beck. 1978. "Introduction." In Women in the Muslim World, eds. Lois Beck and Nikki Keddie, 1-34. Cambridge, MA: Harvard University Press.

Kensinger, Loretta. 2003. "Plugged in Praxis: Critical Reflections on U.S. Feminism, Internet Activism, and Solidarity with Women in Afghanistan." Journal of International Women's Studies 5(1):1-28. Retrieved 19 November 2003, from http://www.bridgew.edu/SoAS/jiws/Nov03/praxis\%20kensinger.pdf.

Lacayo, Richard. 2001. "About Face." Time, 3 December, 34-49.

Lazreg, Marnia. 1994. The Eloquence of Silence: Algerian Women in Question. New York: Routledge.

"Life of Women Under Taliban Regime in Afghanistan." 2001. NBC Nightly News, 4 October. NBC. Retrieved 18 June 2004, from http://www.lexis-nexis .com.

Liu, Melinda. 2001. "'Now I See the Sunlight.'” Newsweek, 26 November, 46.

Majid, Anouar. 1998. "The Politics of Feminism in Islam." Signs: Journal of Women in Culture and Society 23(2):321-61.

Mani, Lata. 1998. Contentious Traditions: The Debate on Sati in Colonial India. Berkeley: University of California Press.

"Mavis Leno, Chair of the Feminist Majority Foundation, Discusses the Oppression Against Women in Afghanistan by the Taliban." 2001. Today, 2 October. NBC. Retrieved 18 June 2004, from http://www/lexis-nexis.com.

Moghissi, Haideh. 1999. Feminism and Islamic Fundamentalism: The Limits of Postmodern Analysis. London: Zed Books.

Mohanty, Chandra Talpade. 2002. "'Under Western Eyes' Revisited: Feminist Solidarity Through Anticapitalist Struggles." Signs: Journal of Women in Culture and Society 28(2):499-535.

- 1991a. "Cartographies of Struggle: Third World Women and the Politics of Feminism." In Third World Women and the Politics of Feminism, eds. Chandra Talpade Mohanty, Ann Russo, and Lourdes Torres, 1-47. Bloomington: Indiana University Press.

_ 1991b. "Under Western Eyes: Feminist Scholarship and Colonial Discourses." In Third World Women and the Politics of Feminism, eds. Chandra Talpade Mohanty, Ann Russo, and Lourdes Torres, 51-80. Bloomington: Indiana University Press.

Mojab, Shahrzad. 1998. "'Muslim' Women and 'Western' Feminists: The Debate on Particulars and Universals." Monthly Review 50(7):19-31.

Ozernoy, Ilana. 2001. "Liberation Day." U.S. News \& World Report, 26 November, 30.

Physicians for Human Rights. 1998. The Taliban's War on Women: A Health and Human Rights Crisis in Afghanistan. Boston: Physicians for Human Rights. 
Rawi, Mariam. 2004. "Betrayal." New Internationalist 364(January/February). Retrieved 27 June 2004, from http://www.newint.org/issue364/betrayal.htm.

"Revolutionary Afghan Women's Association Explains Status of Women in Afghanistan." 2001. 20/20, 3 October. ABC. Retrieved 18 June 2004, from http://www.lexis-nexis.com.

Revolutionary Association of the Women of Afghanistan. n.d. "RAWA's Standpoints." Retrieved 26 January 2005, from http://www.rawa.org/points.html.

Roane, Kit R., and Ilana Ozernoy. 2001. "Afghan Women Find New Hope." U.S. News \& World Report, 3 December, 22-4.

Said, Edward W. 1979. Orientalism. New York: Vintage Books.

Schick, Irvin Cemil. 1990. "Representing Middle Eastern Women: Feminism and Colonial Discourse." Feminist Studies 16(2):345-80.

Song, Sora. 2001. "Headgear 101." Time, 12 November, 31.

Spivak, Gayatri Chakravorty. 2003. Death of a Discipline. New York: Columbia University Press.

- 1999. A Critique of Postcolonial Reason: Toward a History of the Vanishing Present. Cambridge, MA: Harvard University Press.

. 1987. In Other Worlds: Essays in Cultural Politics. New York: Methuen.

Sylvester, Christine. 1994. Feminist Theory and International Relations in a Postmodern Era. Cambridge, UK: Cambridge University Press.

Tickner, J. Ann. 2001. Gendering World Politics: Issues and Approaches in the Post-Cold War Era. New York: Columbia University Press.

United Nations. 2000. Report of the Special Rapporteur on Violence Against Women, Its Causes and Consequences: Addendum-Mission to Pakistan and Afghanistan (1-13 September 1999). Prepared by Radhika Coomaraswamy, 13 March. Retrieved 8 January 2005, from http://www.un.org/womenwatch/ afghanistan/reports.html.

"Unveiled." 2001. 60 Minutes II, 10 October. CBS. Retrieved 18 June 2004, from: http://www.lexis-nexis.com.

Vasquez, John A. 1983. The Power of Power Politics: A Critique. New Brunswick, NJ: Rutgers University Press.

Whitworth, Sandra. 1994. Feminism and International Relations: Towards a Political Economy of Gender in Interstate and Non-Governmental Institutions. New York: St. Martin's Press.

Zulfacar, Maliha. 2004. Phone interview with Mary E. Husain, 7 December. 